\title{
TOP TEN MYTHS OF SOCIAL SECURITY REFORM
}

\author{
Jeffrey Brown, Kevin Hassett and Kent Smetters* \\ CRR WP 2005-11 \\ Released: October 2005 \\ Draft Submitted: September 2005
Center for Retirement Research at Boston College
550 Fulton Hall
140 Commonwealth Ave.
Chestnut Hill, MA 02467
Tel: 617-552-1762 Fax: 617-552-0191
http://www.bc.edu/crr

\begin{abstract}
* Jeffrey R. Brown is an assistant professor of finance at University of Illinois' College of Commerce and Business Administration. Kevin Hasset is Resident Scholar and Director of Economic Policy Studies at American Enterprise Institute. Kent Smetters is the Associate Professor of Insurance and Risk Management at The Wharton School, University of Pennsylvania. The research reported herein was performed pursuant to a grant from the U.S. Social Security Administration (SSA) to the Center for Retirement Research at Boston College (CRR). The findings and conclusions are solely those of the authors and do not represent the views of SSA, any agency of the Federal Government, or Boston College. The authors thank Andrew Biggs, Andy Eschtruth, Jason Furman, Jeffrey Liebman, and Olivia Mitchell for helpful comments and/or discussions and Kathryn Newmark and Gordon Gray for expert research assistance. This paper is forthcoming in the Elder Law Journal.
\end{abstract}

(C) 2005, by Jeffrey Brown, Kevin Hasset, and Kent Smetters. All rights reserved. Short sections of text, not to exceed two paragraphs, may be quoted without explicit permission provided that full credit, including (C) notice, is given to the source. 


\title{
About the Center for Retirement Research
}

The Center for Retirement Research at Boston College, part of a consortium that includes a parallel centers at the University of Michigan and the National Bureau of Economic Research, was established in 1998 through a grant from the Social Security Administration. The goals of the Center are to promote research on retirement issues, to transmit new findings to the policy community and the public, to help train new scholars, and to broaden access to valuable data sources. Through these initiatives, the Center hopes to forge a strong link between the academic and policy communities around an issue of critical importance to the nation's future.

\author{
Center for Retirement Research at Boston College \\ 550 Fulton Hall \\ 140 Commonwealth Ave. \\ Chestnut Hill, MA 02467 \\ phone: 617-552-1762 fax: 617-552-1750 \\ e-mail: crr@bc.edu \\ http://www.bc.edu/crr
}

\section{Affiliated Institutions:}

American Enterprise Institute

The Brookings Institution

Center for Strategic and International Studies

Massachusetts Institute of Technology

Syracuse University

Urban Institute 


\section{Abstract and Policy Abstract}

This paper critically examines ten leading myths that have gained currency in the debate about reforming the U.S. Social Security system, including myths that have been propagated by both proponents and opponents of including personal accounts as part of any reform package. 


\section{Introduction}

The U.S. Social Security system has been one of the most successful public policy programs in our nation's history. ${ }^{1}$ Established during the depths of the Great Depression, the benefits provided through the Social Security system have helped to prevent poverty among millions of Americans after retirement, during periods of disability, or after the death of a family breadwinner. $^{2}$ Unfortunately, the pay-as-you-go financial structure of the system is not well designed to handle the substantial demographic changes that are underway in the United States. Estimates by the Office of the Chief Actuary of the Social Security Administration indicate that the existing combination of scheduled taxes and scheduled benefits leaves an \$11 trillion hole in the system over an infinite time horizon. ${ }^{3}$ As a result, the only way that Social Security can continue to pay the currently-scheduled benefits to future generations is to impose an ever-larger tax burden on younger workers. ${ }^{4}$

While academic researchers and public policy experts have long recognized that the existing combination of scheduled benefit levels and scheduled tax rates is not sustainable in the long run, ${ }^{5}$ Social Security has been viewed as politically "untouchable.”6 While there have been periods of time during which political leaders have made extensive efforts to raise awareness

\footnotetext{
${ }^{1}$ The formal name of the U.S. Social Security system is the Old Age Survivors and Disability Insurance program, or OASDI.

2 Peter A. Diamond and Peter R. Orszag, "Why We Can Afford Social Security," Generations: Journal of the American Society on Aging 29, no. 1 (2005): 47-52. For a more in-depth analysis of the historical evolution of Social Security, see Sylvester Schieber and John Shoven, The Real Deal: The History and Future of Social Security (New Haven: Yale University Press, 1999).

${ }^{3} 2005$ Annual Report of the Board of Trustees of the Federal Old-Age and Survivors Insurance and Disability Insurance Trust Funds, 23 March 2005, p.12, http://www.ssa.gov/OACT/TR/TR05/index.html.

${ }^{4}$ Jeffrey R. Brown, “The Case for Pre-funding Social Security,” Generations: Journal of the American Society on Aging 29, no. 1(2005): 53-58. Also see John Cogan and Olivia Mitchell, "Perspectives from the President's Commission on Social Security Reform,” Journal of Economic Perspectives 17, no. 2 (2003): 149-172.

${ }^{5}$ For one of literally hundreds of examples, see "Report of the 1994-1996 Advisory Council on Social Security," http://www.ssa.gov/history/reports/adcouncil/report/toc.htm.

${ }^{6}$ Richard L. Kaplan, “Top Ten Myths of Social Security,” Elder Law Journal 3, no.2 (1995).
} 
about Social Security, ${ }^{7}$ the issue reached a fevered pitch only after the re-election of President Bush in November 2004. In a press conference the day after the election, President Bush announced that "I earned capital in the campaign, political capital, and now I intend to spend it" on Social Security and other priorities. ${ }^{8}$ Social Security reform featured prominently in the President's State of the Union address on February 2, 2005, which was then followed by a multistate tour designed to build public support for reform.

Over this same period, opponents of the President's Social Security reform plan initiated a major political campaign of their own. Democrats in the U.S. House and Senate unified themselves in opposition to the President’s plan to "privatize” Social Security. Interest groups such as the AARP launched a multi-million dollar public relations and advertising campaign against the inclusion of individual accounts in Social Security.

Thus, in addition to being an important public policy and economic issue, Social Security is a highly controversial political issue. In this highly politicized environment, a number of "myths" about the impact of reform have gained some currency in the public debate. Both opponents and proponents of personal accounts have contributed to the mythology surrounding Social Security reform. In the spirit of a previous article published in this journal that examined the top ten myths of Social Security, ${ }^{9}$ the purpose of this article is to critically examine ten leading myths of Social Security reform in the United States. ${ }^{10}$

\footnotetext{
${ }^{7}$ For example, during 1998, President Clinton held regional conferences, a White House conference, and a Congressional summit, followed by the announcement of a reform plan in his 1999 State of the Union Address. Similarly, during his first year in office, President Bush formed the bipartisan President's Commission to Strengthen Social Security, which issued its final report in December 2001.

${ }^{8}$ George W. Bush, "President Holds Press Conference," White House press release, 4 November 2004, http://www.whitehouse.gov/news/releases/2004/11/20041104-5.html.

${ }^{9}$ Kaplan (1995).

${ }^{10}$ Another article examining ten myths of public pension reform from a more international perspective is Peter Orszag and Joseph Stiglitz, "Rethinking Pension Reform: Ten Myths about Social Security Systems," http://www.worldbank.org/knowledge/chiefecon/conferen/papers/rethinking.pdf.
} 


\section{Myth 1: Social Security is Financially Sound for "Decades to Come"}

A leading argument against reform of the Social Security system is that "Social Security continues to be strong and remains on solid ground for decades to come.”11 According to recent polls, about a quarter of Americans think that Social Security has no problems or only minor problems. ${ }^{12}$ In another set of polls, with slightly different response choices, the numbers of the relatively less concerned was even higher-about 40 percent of respondents said that the financial situation of Social Security today is in no trouble or just some trouble. ${ }^{13}$ When asked about the status of Social Security farther down the road, most people grow more concerned, but a significant percentage remains relatively unconcerned. ${ }^{14}$ In one poll that gave an open-ended time frame- - If changes are not made, do you think the Social Security system is heading for a crisis down the road, or not?”-23 percent of people still thought there would be no crisis. ${ }^{15}$

Implicit in this unworried view is that it is therefore okay to "do nothing" to fix Social Security. Defenders of this view point to the fact that the Social Security Trust Fund ${ }^{16}$ is projected to have sufficient resources to pay full retirement benefits through the year 2041 according to the Social Security Trustees. ${ }^{17}$ While it is true that the date of Trust Fund exhaustion is several decades away, this fact is not particularly salient when it comes to analyzing the broader economic or budgetary implications of the Social Security system.

\footnotetext{
11 "Senate Democrats Fact Sheet on Social Security Trust Fund," 23 March 2005, http://reid.senate.gov/record.cfm?id=234461.

${ }^{12}$ Gallup/CNN/USA Today, February 2005; Washington Post/Kaiser/Harvard, February 2005; Quinnipac, March 2005. Poll data cited here, and elsewhere in this paper, are from "AEI Public Opinion Study: Attitudes about Social Security Reform,” 1 July 2005, http://www.aei.org/publications/filter.,pubID.14884/pub_detail.asp.

${ }^{13}$ NBC/Wall Street Journal, May 2005; CBS/New York Times, June 2005; NPR, February 2005.

${ }^{14}$ NBC/Wall Street Journal, January 2005; CBS/New York Times, February 2005.

${ }^{15}$ ABC News/Washington Post, March 2005.

${ }^{16}$ Technically, there are separate trust funds for the Old Age and Survivors Insurance program (OASI) and the Disability Insurance program (DI). For the rest of this paper, we will refer to the combined balances of these funds as the Social Security "Trust Fund."

${ }^{17} 2005$ OASDI Trustees Report, Table II.D1.
} 
To understand this debate from a broad economic perspective, rather than from the narrow perspective of Trust Fund accounting, it is important to understand how the Social Security system is financed. For most of its history, Social Security has been financed strictly on a "pay-as-you-go" basis. This means that in a given year, the taxes paid by workers in that year are immediately spent to provide benefits to individuals who are receiving benefit payments in that year. Thus, in sharp contrast to private sector pension plans, which are required by law to "pre-fund" their future liabilities, the Social Security system does not accumulate assets to offset future benefit obligations. In other words, Social Security is primarily an income transfer system, not a savings program.

One implication of this financing structure is that the required balance between tax rates and benefit payments is sensitive to the ratio of the number of workers, who pay the taxes, to the number of beneficiaries, to whom payments are made. To put this relation in very simple mathematical terms, the following relation will hold in an annually-balanced, pure pay-as-you go system: ${ }^{18}$

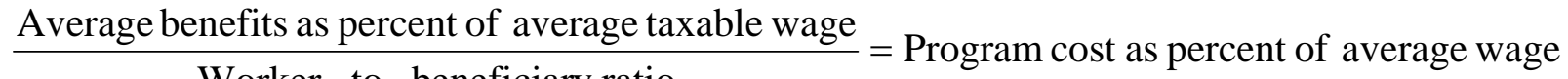
Worker - to - beneficiary ratio

For example, in 2001, the average Social Security benefit was approximately 36 percent of the average worker's wage. In that year, there were 3.4 workers paying into the Social Security system for each beneficiary. Thus, the cost to each worker to support each beneficiary was around 10.6 percent of earnings ( $36 / 3.4 \approx 10.6$ ). Because the payroll tax rate is set at 12.4 percent of covered earnings, Social Security ran a surplus in that year. Indeed, if the ratio of workers to beneficiaries were projected to stay constant at 3.4 for the indefinite future, then we

\footnotetext{
18 The following illustration is based on page 13 of the Interim Report of the President's Commission to Strengthen Social Security, August 2001.
} 
would have the pleasant option of reducing payroll taxes from 12.4 percent to 10.6 percent, or increasing benefits from 36 percent of an average worker's earnings to 42 percent.

Unfortunately, the worker-to-beneficiary ratio is not constant. In 1950, there were over 16 workers per beneficiary. Today we are down to a ratio of 3.3. By the year 2040, as a result of lengthening life expectancies and declining fertility rates, this ratio will likely decline to only 2.0. ${ }^{19}$ To put this into perspective, with a worker-to-beneficiary ratio of only 2.0, a Social Security program that pays benefits equal to 36 percent of the average worker's earnings would require a payroll tax rate of 18 percent, or 45 percent ((18-12.4)/12.4) higher than today’s rate. Alternatively, to live within the existing 12.4 percent payroll tax, benefits would need to decline to under 25 percent of the average worker's earnings, a 30 percent reduction. In short, the payas-you-go structure of the existing Social Security system, when combined with a declining ratio of workers to beneficiaries, requires either that tax rates rise or that benefits fall by a substantial amount over time.

This stylized example closely mirrors the actual cash flow projections prepared by the Office of the Actuary of the Social Security Administration. ${ }^{20}$ Today, Social Security's revenues are approximately 12.7 percent of the taxable earnings base, ${ }^{21}$ while benefit payments are approximately 11.1 percent of the taxable earnings base. ${ }^{22}$ Accordingly, in 2004, Social Security ran a cash surplus of $\$ 67$ billion. ${ }^{23}$ As a result of demographic change, these annual surpluses are projected to peak as a percent of taxable payroll in the year 2008, and then begin a steady decline. By the year 2017, these surpluses will change to deficits, and the deficits will grow

\footnotetext{
${ }^{19} 2005$ OASDI Trustees Report. Table IV.B2.

${ }^{20}$ The following cash flow statistics are from the 2005 OASDI Trustees Report, Table IV.B1.

${ }^{21}$ This number is higher than 12.4 percent because Social Security also receives a small amount of revenue from the income taxation of Social Security benefit payments.

${ }^{22}$ The taxable earnings base includes the earnings of all workers covered under the Social Security system up to a maximum of $\$ 90,000$ of earnings per individual in 2005. This earnings cap is adjusted each year in line with average wage growth.

${ }^{23} 2005$ OASDI Trustees Report, Table II.B1.
} 
every year thereafter. Indeed, by the time today’s college seniors reach their normal retirement age of 67 in the year 2050, the annual cash flow deficits will amount to 4.4 percent of covered wages. $^{24}$ This means that for the system to be in annual cash flow balance, taxes would have to be 36 percent higher, or benefits 26 percent lower, than scheduled under current law. ${ }^{25}$

So what exactly is the meaning of the date of exhaustion of the Social Security Trust Fund? For the past two decades, Social Security has been running cash surpluses each year. These surpluses are credited to the Trust Fund and are invested in special issue U.S. government bonds that earn interest and accumulate over time. As of the end of 2004, the total balance of the trust funds was approximately $\$ 1.7$ trillion. ${ }^{26}$ When Social Security begins running cash deficits around the year 2017, the program will begin to rely on the interest, and soon thereafter, the principal, of the bonds held in the Trust Fund to cover annual cash shortfalls. So long as there are bonds in the trust funds to be redeemed, the Social Security Administration is legally entitled to pay full scheduled benefits to retirees and other beneficiaries. Thus, the one real consequence of Trust Fund exhaustion is that the Social Security Administration will no longer have the legal authority to pay full benefits.

It would be wrong, however, to assume that all is well for another 35 years or more. While the bonds in the Trust Fund are an asset to the Social Security system, they also represent an equally large liability to the U.S. Treasury. Thus, from the perspective of the federal government as a whole, the Trust Fund asset is exactly cancelled by a corresponding Treasury liability. It is roughly akin to an individual borrowing money from himself - because he creates an asset and a liability of equal size, his net worth is unaffected. As a result, when these bonds are redeemed, the Treasury must come up with the resources to fulfill those obligations.

\footnotetext{
242005 OASDI Trustees Report, Table IV.B1.

${ }^{25}$ Calculations based on the 2005 OASDI Trustees Report, Table IV.B1.

${ }^{26} 2005$ OASDI Trustees Report, Table II.B1.
} 
Ultimately, this money can only come from one of three sources: i) higher taxes, ii) reduced government spending, or iii) issuing additional debt to the public, which simply means higher taxes or reduced spending at some point in the future. As clearly explained in President Clinton's fiscal year 2000 budget: “These [Trust Fund] balances are available to finance future benefit payments and other trust fund expenditures - but only in a bookkeeping sense...They do not consist of real economic assets that can be drawn down in the future to fund benefits. Instead, they are claims on the Treasury that, when redeemed, will have to be financed by raising taxes, borrowing from the public, or reducing benefits or other expenditures. The existence of large trust fund balances, therefore, does not, by itself, have any impact on the Government's ability to pay benefits. ${ }^{27}$

But what happened to those surpluses in the year they were generated? From an economic perspective, the Social Security surpluses of the past two decades helped reduce the burden on future generations only to the extent that they increased national saving over this period. Assuming the levels of private saving, other government revenues and other government spending are held constant, adding one dollar to the Social Security surplus adds one dollar to government saving and thus to national saving. However, many analysts believe that the very existence of the Social Security surpluses over the past two decades has made it easier for Congress to run larger deficits in the non-Social Security portion of the budget, essentially using the Social Security surpluses to "hide" larger deficits in the rest of government. To the extent that this is true, the net improvement in national saving from the Social Security surpluses is reduced. Although the effect of the surpluses on national saving is still an open question, ${ }^{28}$

\footnotetext{
${ }^{27}$ Office of Management and Budget, "Budget of the United States Government, Fiscal Year 2000, Analytical Perspectives" (Washington, DC: Government Printing Office, 1999), 337.

${ }^{28}$ Alicia H. Munnell, “Are the Social Security Trust Funds Meaningful?,” Center for Retirement Research at Boston College. Issue in Brief \#30, May 2005.
} 
recent empirical work suggests that the net contribution of Social Security surpluses to national saving has been close to zero. ${ }^{29}$ If so, then as suggested by Douglas Holtz-Eakin, Director of the Congressional Budget Office, "the trust fund is just an accounting exercise.”30

For these reasons, it is incorrect to assert that Social Security is "on solid financial footing for decades to come.”31 The real economic and fiscal pressure that arises from the collision of demographic change and a pay-as-you-go financial structure starts much sooner - as early as the year 2008, when as a result of baby boomers starting to claim benefits, Social Security’s cash flow surpluses will begin to decline. This pressure will necessitate significant changes to the Social Security system and/or the rest of the federal budget, possibly including spending cuts, tax hikes, or increased borrowing. To argue that we can ignore the problem for several decades simply because we have an accounting balance in the Trust Fund is fiscally and economically irresponsible. It is worth noting that even leading economists who strongly oppose President Bush's specific reform plans agree that the fiscal problem facing Social Security is real and that changes in benefits and taxes are required to address the issue. ${ }^{32}$ A constructive debate about the future of Social Security should accept that a problem exists and focus on alternative methods of restoring long-run, sustainable fiscal balance to the program. Simply denying that the problem exists will not make it go away.

\footnotetext{
${ }^{29}$ Kent Smetters, "Is the Social Security Trust Fund a Store of Value?,” American Economic Review: Papers and Proceedings 94, no. 2 (2004): 176-181; Sita Nataraj and John Shoven, "Has the Unified Budget Undermined the Federal Government Trust Funds?,” NBER Working Paper No. 10953, December 2004.

${ }^{30}$ Jodie T. Allen, “More smoke than fire,” U.S. News and World Report, 24 January 2005, 48.

31 "Senate Democrats Fact Sheet on Social Security Trust Fund," 23 March 2005, http://reid.senate.gov/record.cfm?id=234461

${ }^{32}$ For example, see Peter Diamond and Peter Orszag, Saving Social Security: A Balanced Approach (Washington,

D.C.: Brookings Institution Press, 2003).
} 


\section{Myth 2: Economic Growth Will Eliminate the Existing Problem}

A second myth is closely related to the first, but slightly more sophisticated. It has become fashionable to argue that the economic growth assumptions in the Social Security Trustees Report are too pessimistic, and that with higher economic growth, Social Security’s finances will remain strong for the foreseeable future. A recent New York Times column stated that faster growth will "yield a bonanza of payroll tax revenue that will keep the current system sound for generations to come.”33

The basis for this myth is that the Social Security Trustees assume a long-run rate of economic growth over the next 75 years of approximately 1.9 percent, ${ }^{34}$ which is much lower than the historical growth rate of 3.3 percent over the past 40 years. $^{35}$ If one were to simply increase the assumed rate of economic growth to this historical level, Social Security would be technically solvent for the next 75 years.

Importantly, the assumed low rate of economic growth does not arise from a pessimistic view about future productivity growth. Indeed, the long-run rate of productivity growth assumed in the 2005 Trustees Report for the next 75 years is 1.6 percent, which is just slightly below the 1.8 percent rate of productivity growth over the past 40 years. ${ }^{36}$ Rather, the low rate of economic growth stems from the assumed reduction in total employment growth, which was approximately 1.7 percent over the past 40 years, and which is assumed to grow at only 0.2 percent per year in the next 75 years. ${ }^{37}$ While this assumption may be overly pessimistic, some reduction in the

\footnotetext{
33 Paul Krugman, “Many Unhappy Returns,” New York Times, 1 February 2005.

342005 OASDI Trustees Report, Table V.B2.

${ }^{35}$ For the 40-year period from 1963 to 2003, the average growth rate in real GDP was 3.3 percent (2005 OASDI Trustees Report, p. 91).

${ }^{36} 2005$ OASDI Trustees Report, Table II.C1 and p. 82.

372005 OASDI Trustees Report, Table V.B2 and p. 88.
} 
growth rate of total employment is justified, given that the entire baby boom generation will move from being part of the labor force to being entirely out of the labor force over the next 75 years.

More generally, while it is correct that higher rates of economic growth lead to higher tax revenues in the future, it is important to understand that in a wage-indexed system such as ours, future benefit obligations also grow when wages rise. Specifically, the current Social Security benefit formula is designed to hold benefits constant relative to a retiree's average (wageindexed) lifetime income. As average earnings rise, therefore, so do promised benefits. Thus, while economic growth does improve the long-run sustainability of the system, ${ }^{38}$ it does not eliminate the need for policy changes. Indeed, even if the economic growth rate were increased to historical levels, this would only postpone the onset of cash deficits by a few years. ${ }^{39}$

More generally, analysts are no doubt correct to assert that the actuarial and economic assumptions used to evaluate the future cash flow problems of Social Security are, in fact, just assumptions. It is certainly true that any set of projections will, ex post, likely turn out to be wrong. But two points are worth making in this regard. First, uncertainty about the future cuts both ways, suggesting that while Social Security's future cash flows may turn out to be better than expected, they could also be worse than expected. Prudent planning for the future should actually place more weight on the downside risk than on the upside potential. Second, there are other assumptions made by the Trustees that arguably understate the future cash flow problems facing the system.

\footnotetext{
${ }^{38}$ Because benefits are not indexed to wages after retirement, a permanent increase in wage growth does improve Social Security's cash flow situation.

${ }^{39}$ Rudolph G. Penner, “Can Faster Growth Save Social Security?,” Center for Retirement Research at Boston College, Issue in Brief\#15, December 2003.
} 
The 2003 Technical Panel on Assumptions and Methods, which is an independent panel of expert actuaries, economists, and demographers appointed by the independent and bipartisan Social Security Advisory Board, offered a number of recommendations for changes to the assumptions used in the actuarial analysis of Social Security. This panel did, in fact, recommend that the actuaries use a higher rate of wage growth going forward, which reduces the size of the unfunded obligation facing Social Security by about $\$ 0.3$ trillion over the next 75 years.

However, they also recommended changes in the mortality assumptions that increased the size of the unfunded obligation over this period by $\$ 0.5$ trillion. All of their recommendations, taken in their entirety, actually served to increase the size of the unfunded obligations facing Social Security. ${ }^{40}$

The bottom line is that, yes, future projections are subject to considerable uncertainty. But to avoid making politically difficult policy corrections based on the fact that the future might turn out better than expected is unwise. Rather than using the existence of uncertainty as an excuse to avoid responsible policy actions, policymakers should look for ways to reform the Social Security system so that it is more resilient to unexpected demographic and economic shocks.

\section{Myth 3: Social Security is in "Crisis" and Will Not Be There When Today's Younger Workers Retire}

At the other end of the spectrum with regard to the urgency of the Social Security problem are those that claim that the system is already in "crisis." Reformers from both parties have used such urgent rhetoric to strengthen support for political action. Congressional

\footnotetext{
${ }^{40}$ The current size of the 75-year unfunded obligation of the Social Security system is $\$ 3.5$ trillion under intermediate assumptions, and the net increase from the Panel's recommendations is $\$ 0.2$ trillion. (2003 Technical Panel on Assumptions and Methods, "Report to the Social Security Advisory Board," October 2003, p. 10, http://www.ssab.gov/documents/2003TechnicalPanelRept.pdf)
} 
Republicans leading the reform efforts today frequently refer to the crisis in Social Security, while in the late 1990s, top Democrats pledged to use the budget surplus to "save Social Security first." ${ }^{, 1}$ A significant percentage of the American public has absorbed this message: according to the most recent polls, 14 to 27 percent think Social Security is currently in crisis. ${ }^{42}$

The fact that Social Security faces an $\$ 11$ trillion present value shortfall, $\$ 4$ trillion of which occurs over the next 75 years, clearly indicates that the program faces a severe funding problem. ${ }^{43}$ It is also certainly the case that acting sooner rather than later to address these financial shortfalls ought to be a fiscal priority for U.S. policymakers. Whether such a problem presents an immediate crisis, however, is certainly debatable, and this may be reflected in the ambiguous poll numbers mentioned previously. In the very short term, Social Security can certainly continue "business as usual." For the next 12 years, Social Security will continue to run a positive, albeit declining, cash flow. Benefits to current retirees are simply not at risk, neither economically nor politically. Naturally, the longer we conduct "business as usual," the more intractable the problem becomes and the more future generations have to bear the cost, but to call it a "crisis" almost surely overstates the near-term implications. It is more accurate to say that we need to act now to address the looming shortfall before it becomes a true crisis.

The crisis language also underscores a widely-held belief that Social Security "will not be there" in the future. One recent poll found that 24 percent of Americans think there will be no money in the Social Security system when they retire; ${ }^{44}$ another poll found that 46 percent are not confident at all that Social Security will still be providing retirement benefits when they

\footnotetext{
${ }^{41}$ See, for example, “Senators Introduce Bill to Stop the Raid on Social Security,” press release, Office of Senator DeMint, 23 June 2005, http://demint.senate.gov/index.cfm?Fuseaction=PressReleases.View\&PressRelease_id=252; "Press Conference with U.S. Senators re: Legislation to 'Stop the Raid on Social Security,'” Federal News Service, 23 June 2005; National Council of Senior Citizens Rally, Federal News Service, 24 September 1998.

${ }^{42}$ Gallup/CNN/USA Today, February 2005; Washington Post/Kaiser/Harvard, February 2005; Quinnipac, March 2005; NBC/Wall Street Journal, May 2005; CBS/New York Times, June 2005.

${ }^{43} 2005$ OASDI Trustees Report, Table IV.B6.

${ }^{44}$ Los Angeles Times, January 2005.
} 
retire. ${ }^{45}$ This fear is even stronger among the younger generations: a famous poll among younger workers fielded in 1994 indicated that only 28 percent of respondents believed that Social Security would pay benefits to them when retired, compared to 46 percent who said they believed in UFOs. ${ }^{46}$

The idea that Social Security "will not be there" for younger workers unless the system changes is incorrect. ${ }^{47}$ Under the intermediate assumptions of the Social Security Trustees, even if policy makers make no changes to the system and Social Security is unable to pay full benefits after the Trust Fund is exhausted, future retirees will still get approximately three-quarters of what is scheduled under current law. ${ }^{48}$ So the question facing today’s younger workers should not be "will I get anything out of Social Security?” but rather "just how much will I receive when I retire, and how much will I have to pay in taxes before I get there?” And, as part of the current debate, “will I be permitted to invest part of my contributions in personal accounts?”

\section{Myth 4: Personal Accounts Can Save Social Security without Benefit Cuts or Tax Increases}

As already noted, the financial problem facing Social Security arises primarily due to the unsustainability of a pay-as-you-go system in the face of a declining worker-to-beneficiary ratio. The simple economic and mathematical reality is that there is no easy, costless, or "pain-free" solution to this problem. To restore the system to long-run financial balance, some generation must see its consumption reduced, either through higher taxes or through lower Social Security

\footnotetext{
${ }^{45}$ NBC/Wall Street Journal, December 2004.

46 "Social Security: The Credibility Gap,” Third Millennium survey, conducted by Luntz Research Companies and Mark A. Siegel and Associates, September 1994, http://www.thirdmil.org/publications/surveys/surv7.html.

${ }^{47}$ This point was also made by Kaplan (1995).

${ }^{48}$ According to Table IV.B1 of the 2005 OASDI Trustees Report, the ratio of the income rate to the cost rate in the year 2040, the approximate date of trust fund exhaustion, is $13.26 / 17.52=.757$, which means that benefits would need to be cut by 24.3 percent in order to balance the system in that year.
} 
benefits than are currently scheduled. As Federal Reserve Chairman Alan Greenspan aptly noted, the only other alternative is to "have legislation which repeals the laws of arithmetic."49

This mathematic and economic reality has not stopped some proponents of personal accounts from arguing that there is a "free lunch" available, if only we would divert existing tax revenue into personal accounts. The idea behind this approach is that the higher rates of return that would be achieved by investing Social Security funds in the stock market (or other private investments) would allow us to deliver future benefits that are greater than or equal to the existing level of scheduled benefits without raising taxes. For example, a March 31, 2005 letter to Congress from the Social Security Coalition states, "With well designed personal accounts, workers would earn much higher returns than Social Security even promises; let alone what it can pay....Indeed, personal accounts are the only solution to this problem. Tax increases and future benefit cuts would only make the problem worse....Therefore, we urge you to support Social Security reform legislation focused solely on personal accounts, without tax increases or cuts in future promised benefits. ${ }^{, 50} \mathrm{~A}$ recent poll shows that 35 percent of respondents also believe we can get a free lunch, agreeing that it is possible to ensure the long-term future of Social Security without either raising taxes or cutting benefits. ${ }^{51}$

The only problem with this approach is a simple one - it is not true. If it were possible to provide guaranteed benefits that are higher than today’s promised benefits with no tax increases, then every single Republican politician, economist, and policy analyst, as well as most

Democrats, would be falling over themselves in a rush to sign on. Social Security reform would

\footnotetext{
${ }^{49}$ Testimony of Federal Reserve Chairman Alan Greenspan, Senate Committee on Banking, Housing and Urban Affairs, 12 February 2004, in response to a question by Senator Jack Reed about the difficult choices facing policy makers when dealing with Social Security and other entitlement programs.

50 "Social Security Coalition to Congress Endorsing Personal Accounts," 30 March 2005, http://www.atr.org/content/pdf/2005/mar/sscoalitionletter\%2003-30-05.pdf.

${ }^{51}$ Gallup/CNN/USA Today, April-May 2005.
} 
likely already be a thing of the past. After all, filling an $\$ 11$ trillion shortfall with no new revenue along with a guarantee that nobody would see their benefits reduced is a politician's dream - all gain, and no pain.

The fallacy of this argument, which is nearly universally understood by academic economists of all political stripes, has been known for decades ${ }^{52}$ and is perhaps most clearly explained in work by Geanakoplos, Mitchell, and Zeldes. ${ }^{53}$ To begin with, it is important to understand why Social Security's internal rate of return is lower than even a risk-free government bond. As explained by the authors, "projected Social Security returns are low, not because of waste or inefficiency, but because the system developed as a primarily unfunded, payas-you-go system" in which the early cohorts of retirees received large, positive net transfers. ${ }^{54}$ In other words, early generations of Social Security participants received far more in benefits than they paid in taxes, or, alternatively, these early participants can be viewed as having received a rate of return on their Social Security contributions that was well above market rates. These authors calculate that, in 1997 dollars, the cohorts born before 1937 received approximately $\$ 10$ trillion in positive transfers, i.e., benefit payments in excess of the economic value of their contributions. These transfers of wealth to the early generations are sometimes called the "legacy cost" of Social Security. ${ }^{55}$

It can be shown mathematically that "since past cohorts received positive net transfers, some present and future cohorts must receive negative net transfers" and "[b]ecause past cohorts received rates of return greater than market rates, current and/or future cohorts must receive rates

\footnotetext{
${ }^{52}$ See, for example, F. Breyer, "On the Intergenerational Pareto Efficiency on Pay-as-you-go Financed Pension Systems,” Journal of Institutional and Theoretical Economics 145 (1989): 643-58.

${ }^{53}$ Geanakoplos, John, Olivia S. Mitchell and Stephen P. Zeldes, "Would a Privatized Social Security System Really Pay a Higher Rate of Return?," in Framing the Social Security Debate: Values, Politics and Economics, ed. D. Arnold, M. Graetz, and A. Munnell, 137-157 (Washington, D.C.: Brookings Institution Press, 1998).

${ }^{54}$ Geanakoplos, Mitchell, and Zeldes, 144.

${ }^{55}$ See, for example, Diamond and Orszag (2003).
} 
of return lower than market rates. ${ }^{, 56}$ In essence, the current generation of workers has inherited a large "legacy cost," which can be viewed as a form of implicit debt that needs to be serviced or paid off. The need to service this "debt” reduces rates of return from the system. Geanakoplos et al., calculate that "implicit interest payments explain why young workers may expect only 75 percent of their taxes back in (the present value of) benefits over their lifetimes." ${ }^{57}$ Importantly, this cost exists regardless of whether payroll taxes continue to flow into the current system or are instead diverted into personal accounts. In other words, the main factor causing the return on the Social Security system to be below the return on a risk-free asset would still exist even if we allowed workers to invest in personal accounts.

Economists therefore understand that the reason for the low returns from Social Security is not bad investment policies, inefficiency, high costs, or government waste. Rather, the difference in the rate of return between Social Security and a risk-free government security is due to the cost of dealing with the trillions of dollars of wealth transfers made to the early generations of Social Security retirees through our pay-as-you-go system.

Economists also recognize, however, that if Social Security reform actually succeeds at increasing national saving, then the pre-tax rate of return that our nation achieves on the capital investment can be quite high, averaging approximately 8.5 percent from $1959-1996 .{ }^{58}$ Of course, achieving an increase in national saving through Social Security reform requires that government spending is reduced and/or that government revenues increase. Many analysts fail to adequately understand these conditions for increasing national saving and thus wrongly conclude that simply investing existing Social Security revenues in the stock market will

\footnotetext{
${ }^{56}$ Geanakoplos, Mitchell, and Zeldes, 146-7.

${ }^{57}$ Ibid., 148.

${ }^{58}$ James Poterba, "The Rate of Return to Corporate Capital and Factor Shares: New Estimates Using Revised National Income Accounts and Capital Stock Data,” Carnegie-Rochester Conference Series on Public Policy 48 (1998): 211-46.
} 
necessarily generate higher returns. "Myth 5" below will address this issue more in-depth, but a problem with simple rate of return comparisons is that these analyses often fail to acknowledge that higher rates of return on stocks are simply the market's compensation for risk. Increasing the expected return of a portfolio carries with it the possibility that the long-term financial status of the system could be worsened if equity markets in the future experience a series of negative shocks. To put it simply, if we could eliminate the entire \$11 trillion financing shortfall simply by investing in stocks, then why stop there? Why not simply have the government borrow $\$ 10$ trillion, invest it in the stock market, and then dramatically cut income tax rates? Few economists would view such a proposal as prudent fiscal policy. ${ }^{59}$

To be clear, there are many sound economic reasons to support a move to personal accounts, including i) that personal accounts may represent a more effective mechanism than the trust funds to save Social Security surpluses in an economically meaningful way, ii) that personal accounts may improve labor supply incentives, and iii) that personal accounts may extend the benefits of asset ownership to a much broader cross-section of the U.S. population than is the case today. But none of these advantages to personal accounts in any way obviate the need for other reforms that reduce long-run expenditures or increase the long-run revenue stream dedicated to Social Security. Indeed, it was a recognition of this economic reality that led President Bush, despite the potential political risk of doing so, to endorse additional steps to

\footnotetext{
${ }^{59}$ Although it should be noted that examples of such policies abound. For example, in June 2003, the state of Illinois sold $\$ 10$ billion in general obligation bonds for pension funding purposes. Of this $\$ 10$ billion, $\$ 7.3$ billion was distributed to the state's various retirement systems for immediate investment, while the other $\$ 2.7$ billion was used to fund the state's pension contributions for the fourth quarter of 2003 and all of 2004 . As stated on the website of the State Comptroller's Office, "The objective is that a higher return on the investments (estimated at $8.5 \%$ by retirement system actuaries) will yield savings to the state as the reduction in pension contributions is in excess of the required debt service amount" (http://www.ioc.state.il.us/FiscalFocus/current/article.cfm?ID=138). In short, the basic idea is that the State of Illinois is hoping that the investment proceeds from the $\$ 7.3$ billion invested in private markets will be sufficient to cover the interest cost on the entire $\$ 10$ billion of bonds.
} 
reform Social Security, such as moving from wage indexing to progressive price indexing, which would substantially reduce long-run Social Security expenditures. $^{60}$

\section{Myth 5: Allowing Individuals to Redirect Their Contributions from the Trust Fund to Personal Accounts Will Provide a Higher Rate of Return.}

A leading selling point among advocates of personal accounts is that the rate of return that individuals can achieve through personal accounts is much greater than the return that is available through the existing Social Security system. For example, the current administration emphasizes how the money in personal accounts "would have the opportunity to earn a higher rate of return than anything the current system could provide." ${ }^{61}$ The higher rate of return argument is, indeed, a perennial favorite among elected officials. ${ }^{62}$ Many Americans are also convinced that private accounts will give them higher returns: over a third of those surveyed think they would receive more money in retirement if they were allowed to invest part of their Social Security taxes. ${ }^{63}$

As noted above, if national saving is increased as part of Social Security reform, then the economy does benefit from the high pre-tax marginal return on new capital investment. But this is not the point being made by most reform advocates when they make rate of return comparisons. Rather, they are making a point that a person can get a higher rate of return investing in stocks than leaving their money in the Social Security system. Is this claim accurate?

\footnotetext{
${ }^{60}$ George W. Bush, "Press Conference of the President,” White House press release, 28 April 2005, http://www.whitehouse.gov/news/releases/2005/04/20050428-9.html.

61 "Strengthening Social Security," White House Policy in Focus, http://www.whitehouse.gov/infocus/socialsecurity/.

${ }^{62}$ For example, see the 1999 State of the Union Address, http://www.washingtonpost.com/wpsrv/politics/special/states/docs/sou99.htm.

${ }^{63}$ Associated Press/Ipsos, February 2005.
} 
It is certainly true that an individual (or, for that matter, a centralized fund) can earn an expected rate of return on private investments that is higher than the internal rate of return that the average worker can expect to receive from Social Security. It does not follow, however, that redirecting existing Social Security payroll tax revenue into private investments will necessarily increase the rate of return for participants. There are two basic reasons that this is so. First, when using existing Social Security revenue to finance the private investment, it is necessary to net out the expense of servicing the legacy costs of the system. As already discussed under Myth 4, unless policymakers decide that they will not honor the benefit obligations to current and future retirees, we still need to find the funds to pay those benefits. An accurate comparison of rates of return from Social Security contributions should account for these costs in both the current system and in a mixed system where part of the funds are redirected to personal accounts.

A second issue is that statements about higher rates of return need to be accompanied by appropriate caveats about risk. Basic finance theory teaches that higher expected returns are the reward for bearing increased risk. For example, stocks have a higher expected return than bonds because stocks are riskier than bonds, i.e., stocks will outperform bonds on average, but also carry with them an increased probability of "extreme" outcomes (e.g., experiencing very high, or very low, even negative, returns). This must be true in a market equilibrium as long as investors like high returns and dislike risk. To see this, suppose that there are two assets A and B that offer different rates of return (e.g., $R_{A}>R_{B}$ ) but the same level of risk. Then all risk averse investors will prefer asset A, and thus they will all try to buy A and sell B. This will drive up the price of asset A and drive down the price of asset B. At some point, the prices will adjust to the point that expected future returns on the two assets are equal, and investors will be indifferent 
between holding A or B. With well-functioning financial markets, the only way an asset will offer a higher expected rate of return is if it carries with it some risk that cannot be diversified away. Thus, proponents of accounts are correct to say that investment in stocks can provide people with higher expected returns, but only so long as they acknowledge the risk that accompanies it. Too often, proponents of personal accounts treat the higher returns as if they are a sure thing.

The fact that stocks outperform bonds in expectation, or on average, is often misinterpreted to suggest that stocks may be riskier in the short run, but that stocks are not risky in the long run. This is clearly false. All assets have some risks associated with them, and the market prices these risks in the context of current market perceptions. While it is true that stocks have outperformed bonds in the United States over any 30-year period since $1926,{ }^{64}$ it is not the case that stocks are currently perceived by market participants to be less risky than bonds in the long run. If stocks were less risky in the long run, then long-term investors (e.g., pension funds, insurance companies, individuals with long time horizons, etc.) would not require a higher expected return to be willing to hold them. Another way of viewing this is as follows: if stocks were not risky in the long run, then the financial services industry would be quite willing to provide - maybe even for free - long-term financial contracts that provided a rock solid guarantee that investors would not lose money if they held on to a broadly diversified stock portfolio for, say, 30 years. Yet such long-term put option contracts do not even exist, let alone exist at low prices. This is because financial market participants believe that the risk of such a contract is increasing with the time horizon, not decreasing.

\footnotetext{
${ }^{64}$ Ibbotson Associates, Stocks, Bonds, Bills, and Inflation Yearbook, 2005.; Jeremy J. Siegel, Stocks for the Long Run (Columbus, OH: McGraw-Hill, 2002).
} 
Yet another way of understanding this issue is to simply realize that a dollar invested in stocks today is worth the same to the marginal investor as a dollar invested in bonds today at today's prices. Both investments are worth one dollar, even though the stock has a higher expected return than the bond. The reason is that this higher expected return is precisely equal to what the marginal investor requires to be willing to bear the extra risk associated with holding stock. Thus, in the parlance of financial economics, the "risk-adjusted return" to stocks and bonds is equal for a diversified investor. Only households who currently don't have an easy opportunity to invest in stocks -- some employers, for example, don’t offer 401(k) plans -- could potentially benefit from an easier access to the stock market.

It is true that economists have spent an enormous amount of energy studying the "equity premium puzzle"; that is, why stocks have performed so much better than bonds in the long run at lower realized levels of return volatility. ${ }^{65}$ If one believes that the best explanation of the puzzle is that market participants have underpriced stocks historically---the market has been "wrong" about equity risk---then one would be willing to invest in equities and expect to reap higher returns. Under this scenario, however, one could acquire the high returns inside or outside of Social Security. If one were sure that the equity premium existed because of a market error, then one should fund all government activities by arbitraging the equity premium, as mentioned before.

Economists generally do not advocate such extreme measures because there is uncertainty concerning the causes of the equity premium. It is possible that the market is right about equity risk and that the economists puzzled by high returns have used flawed or incomplete models. It would be quite odd to argue that only Social Security should rely on the

\footnotetext{
${ }^{65}$ Rajnish Mehra and Edward C. Prescott, "The Equity Premium: A Puzzle,” Journal of Monetary Economics 15, no. 2 (1985): 145-161.
} 
equity premium for finance if the equity premium were irrationally high. Given the state of academic dispute on this issue, one should conservatively rely on market prices for assets when assessing values. The equity premium puzzle suggests that accounts may have an upside, but the market as a whole feels that the risks are balanced at current prices.

To summarize, advocates of personal accounts are correct to say that investing in stocks can provide a higher expected return than bonds, so long as they acknowledge the increased risk that comes along as part of the package. However, a comparison of stock market rates of return to the internal rate of return on Social Security is not valid, unless the cost of servicing the legacy debt is first netted out of the comparison.

\section{Myth 6: Personal Accounts will Worsen Social Security's Financial Problem}

Senate Democrats have also argued that “the President's privatization plan worsens the problem.”66 They go on to argue that “[b]ecause that plan would cut Social Security’s funding by diverting payroll taxes into privatized accounts, full guaranteed benefits could be paid only until 2030. This is eleven years earlier than under current law." ${ }^{, 67}$

This statement is misleading because it treats the money flowing into the Social Security personal accounts as somehow permanently leaving the Social Security system, when in fact the personal account balances will be used to provide future benefits to retirees and thus reduce the future cost of the pay-as-you-go portion of the program. Indeed, the President's personal account proposal has designed the accounts to be "actuarially fair," meaning that the long-run effect of personal accounts neither increases nor decreases the present value of the funding shortfall. This is achieved by requiring individual participants who choose the accounts to

\footnotetext{
66 “Senate Democrats Fact Sheet on Social Security Trust Fund,” 23 March 2005, http://reid.senate.gov/record.cfm?id=234461.

${ }^{67}$ Ibid.
} 
accept a future "benefit offset" that is equal, in present value, to the amount of money they are diverting into the accounts.

The key analytical point to understand is that, given the way the accounts and the benefit offsets have been designed in the current administration's proposal, personal accounts neither hurt nor help the long-run financial situation facing Social Security. It is true, as will be discussed in Myth 9 below, that a transition from a pure pay-as-you-go system to a mixed system that includes personal accounts will change the timing of the revenues needed to finance the system. The need to pay benefits to current retirees while simultaneously funding the accounts does require more resources in the short run, but these additional resources (plus interest) are recaptured in the form of lower revenue needs in future decades. Indeed, if one of the goals of reform is to reduce the financial burden on future generations by reducing the consumption (increasing the saving) of the current generation, then financing a gradual transition to personal accounts through higher taxes or reduced spending is an effective way to achieve this goal.

\section{Myth 7: Personal Accounts Will Cause Benefit Cuts}

Opponents of PRAs often argue that offering personal accounts will somehow threaten current retirement benefits, and according to one poll, nearly half of Americans agree with them. ${ }^{68}$ This argument is false. There is near-universal bipartisan agreement that benefits of those individuals who are already retired or near retirement will not be reduced by a single penny. Indeed, President Bush has made it one of his core reform principles that reform “must not change Social Security benefits for retirees or near-retirees.”69

Of course, as already noted, any reform proposal - with or without personal accounts -

\footnotetext{
${ }^{68}$ Gallup/CNN/USA Today, December 2004.

69 “Interim Report of the President's Commission to Strengthen Social Security,” August 2001, p. 31, http://www.csss.gov/reports/Report-Interim.pdf.
} 
that seeks to eliminate the large gap between future revenue and future benefit payments must use some combination of a reduction in scheduled benefits or an increase in taxes. Thus, the vast majority of reform proposals that have been introduced in Congress in recent years do contain some reductions in scheduled benefits for future retirees (generally, those born after 1950). However, it is important to note that these reductions in scheduled benefits are not a result of the introduction of personal accounts. Rather, they are the result of the poor fiscal health of the Social Security system that, as already noted, is driven primarily by the demographic shifts occurring in the U.S. It is also important to note that these reductions in scheduled benefits are usually achieved by slowing down the rate of growth in future benefits, rather than by cutting the existing level of benefits. For example, even under the "progressive price indexing” proposal endorsed by President Bush, future retirees would receive a higher level of inflation-adjusted benefits than what today's retirees receive; thus it is difficult to call this a benefit cut, although it would constitute a decline in what is called the Social Security "replacement rate," which is the fraction of pre-retirement earnings that are replaced by Social Security. The only sense in which these changes constitute a cut in the level of the benefit being provided is if one compares them to the level of benefits that are currently scheduled in the law, but for which the system does not have the revenue to pay.

In addition to the sleight of hand of blaming benefit reductions required for restoring solvency on personal accounts, some opponents of personal accounts have also argued that accounts will lead to benefit cuts - ignoring the income from the personal accounts. ${ }^{70}$ Under many reform plans, when existing payroll taxes are redirected into personal accounts, individuals accept a "benefit offset," essentially a corresponding reduction in the traditional benefit paid

\footnotetext{
${ }^{70}$ See, for example, American Association of Retired Persons, "Frequently Asked Questions About Strengthening Social Security,” http://www.aarp.org/money/social_security/Articles/item114995453.html.
} 
from the pay-as-you-go portion of the Social Security system. President Bush’s proposal, for example, requires that individuals who opt for the account give up traditional benefits equal to the annuitized value of the taxes paid into the account accumulated at a 3 percent rate of return. Thus, individuals who choose to use personal accounts and earn a 3 percent return on the account will end up with the same total retirement income as if they had not taken the account. Individuals who earn more than 3 percent per year on average end up with more income, while those who earn less end up with less. Clearly, a discussion of risk and return is appropriate in this context, and rational analysts may disagree over the desirability of such an account. Instead, what some personal account opponents do is simply focus on the reduction in the traditional benefit, without counting the income from the account. As one analyst notes, opponents of personal accounts "seem to assume that the money that goes into the PRAs would disappear, and that none of it would actually be available to pay Social Security benefits. It is less than intellectually honest to subtract money that would go into PRAs from Social Security's income and then to claim that no level of benefits would be financed by the PRAs in the future."71

Personal accounts are a natural candidate to include in a Social Security reform because voluntary accounts have attractive properties that may increase the utility of workers who choose them. If accounts are introduced at the same time that scheduled benefits are reduced or taxes increased, then the positive attributes of the accounts may help to partially offset the negatives of the changes that move the system toward sustainability.

\footnotetext{
${ }^{71}$ David C. John, “The Myth of 40 Percent Benefit Reductions Under Social Security Reform,” The Heritage Foundation Executive Memorandum \#768, 21 August 2001, http://www.heritage.org/Research/SocialSecurity/EM768.cfm.
} 


\section{Myth 8: Personal Accounts are Risky and the Current System is Safe}

Opponents of personal accounts often argue that personal accounts expose individuals to too much risk, in contrast to the very safe benefit they receive from the existing system. There are several problems with this line of reasoning.

First, one of the President's core principles of reform is that participation in the personal accounts be voluntary. As a result, if rational individuals conclude that they would prefer not to participate in personal accounts, there would be no requirement that they do so. Only those individuals who voluntarily choose the accounts would have them.

Second, many reform proposals would allow individuals the opportunity to choose a portfolio allocation that they are comfortable with, including, if desired, a relatively safe bond portfolio. As discussed in myth 5 above, financial markets reward individuals who are willing to take on more risk with higher expected rates of return. In this respect, myth 8 is the opposite mistake that is made by personal account proponents in myth 5 . Account proponents like to talk about higher returns without acknowledging the increased risk. Account opponents like to talk about risk without acknowledging the higher expected returns. The reality is that risk and return come as a package - in efficient markets, higher returns come with higher risk.

Third, it is a mistake to treat the existing Social Security system as being free from risk. The system faces annual cash flow deficits starting in the year 2017 that grow each year thereafter. Unless the system is reformed so that it is placed on a permanently sustainable fiscal path, the political risk of future benefit cuts will grow. Whereas today it is relatively easy to make modest adjustments to benefit levels that are phased in over many decades and that leave current retirees unaffected, such a gradual reform approach will be made much more difficult if we fail to act until the system is already deep in annual cash deficits. 


\section{Myth 9: Transitioning to Personal Accounts is Too Costly}

Perhaps no issue in the Social Security reform debate is less understood than the economic implications of the transition from a pay-as-you-go system to a mixed system that includes personal accounts. Currently, most of the tax revenue paid by today's workers is immediately used to pay benefits to today's retirees. If some of those taxes are diverted instead into personal accounts, then we must still come up with the money to pay full benefits to today's retirees, as well as to today's workers who have already accrued future benefits. The need to simultaneously finance benefit payments to retirees while also funding the accounts is often called the "transition cost," and it is a very real economic and budgetary phenomenon.

What is poorly understood, however, is that these "transition costs" are not new costs at all, but rather a retiming of costs that the Social Security system will eventually have to pay anyway. The money flowing into the personal accounts will eventually be used to finance future benefit payments, which will therefore reduce the level of benefits that will need to be financed by payroll taxes on future workers. If these "transition costs" are fully paid for by reduced consumption of the current generation (such as through increased taxes or reduced government spending), then every dollar spent on the transition would add one dollar to national saving. Such an increase in national saving would be good for long-term economic growth, since national saving is the "fuel" that spurs investment and grows the economy. In this sense, the term "transition investment” seems a much more appropriate label than "transition cost," as the latter term has an incorrect connotation that these funds are somehow a pure cost, as if the money were eaten up in administrative fees or tossed in the ocean. "Transition investment” better captures the economic reality that funding accounts today reduces the financial burden on future 
generations, much the same way that a family saves money when their children are young to reduce the future financial burden when the child enters college.

Of course, the political and budgetary reality may be that we finance some or all of the transition by issuing debt, rather than by raising taxes or reducing expenditures. If the entire transition were financed by issuing debt, then the transition to personal accounts would not increase national saving, and therefore would do nothing to reduce the financial burden on future generations. However, neither would financing the transition with debt worsen the nation's fiscal health. This fact is widely misunderstood. For example, nearly 50 percent of the respondents in one poll said the federal budget deficit would increase significantly if private accounts were enacted. ${ }^{72}$ Another example is the fear expressed by Democrats in Congress that the President's plan will "put us another $\$ 2$ trillion in the red." ${ }^{, 73}$ What these concerns fail to account for is that the President's plan for personal accounts would also reduce the payroll tax liability on future workers by an equivalent $\$ 2$ trillion in present value. In other words, the plan would reduce the future unfunded obligations of Social Security by $\$ 2$ trillion, but increase publicly held debt by $\$ 2$ trillion, resulting in a net zero effect on the overall future tax burden on future generations.

Said differently, the unfunded obligation that the Social Security system is imposing on future workers is approximately $\$ 11$ trillion dollars. If one adds in the $\$ 4.3$ trillion in publiclyheld debt, the net “indebtedness" of the nation is $\$ 15.3$ trillion. ${ }^{74}$ By funding a \$2 trillion

\footnotetext{
${ }^{72}$ Gallup/CNN/USA Today, December 2004.

73 "Democratic Response to the State of the Union Address," 2 February 2005, http://www.cnn.com/2005/ALLPOLITICS/02/02/dem.transcript/.

${ }^{74}$ It is important to note two issues here. First, the "net indebtedness" figures quoted here exclude the much larger unfunded liability imposed by the existing Medicare system, which is estimated to be in excess of $\$ 72$ trillion, according to the 2005 Medicare Trustees Report, not counting general-revenue transfers. Second, an important difference between an unfunded benefit obligation and publicly-held debt is that the latter is backed by the full faith and credit of the U.S. government, whereas unfunded obligations can be increased or decreased by changes in legislation.
} 
transition to actuarially fair personal accounts, the unfunded obligation of Social Security falls to $\$ 9$ trillion, while the publicly held debt rises to $\$ 6.3$ trillion, thus leaving the net indebtedness unchanged. Indeed, when one considers the non-account aspect of the President's plan, often called progressive price indexing, the reduction in future unfunded liabilities is far greater than \$2 trillion, resulting in a net gain to the "balance sheet" of the federal government.

In summary, the transition to personal accounts can serve to increase national saving if it is financed through higher taxes or reductions in government spending. If it is financed by the issuance of publicly held debt, then the transition will not add to national saving. But neither will it increase the net financial burden on future generations. As such, a debt-financed transition to personal accounts would have no significant effect on the size of the burden that we are passing onto the next generation. ${ }^{75}$

\section{Myth 10: Social Security Reform is Bad for the Poor / Women / Minorities}

Opponents of reforming the Social Security system often argue that certain groups will be particularly harmed by reform. ${ }^{76}$ The reality is much more complex for several reasons.

First, it is well documented that the current system is on a fiscally unsustainable path. To be placed back into long-term balance, taxes and/or benefits must eventually change. Therefore, in evaluating how a particular group will be affected by reform, it is important to ask, “Compared to what?” One baseline for comparison that is wholly inappropriate is one that

\footnotetext{
${ }^{75}$ Andrew Eschtruth and Robert Triest, "National Saving and Social Security Reform,” Center for Retirement Research at Boston College. Just the Facts on Retirement Issues \#18, April 2005.

${ }^{76}$ For a few of many examples, see Older Women's League, "Social Security Privatization: A False Promise for Women,” May 2002, http://www.owl-national.org/owlreports/MothersDay2002.pdf; William E. Spriggs, “African Americans and Social Security: Why the Privatization Advocates are Wrong," Dollars \& Sense: The Magazine of Economic Justice, November/December 2004, http://www.dollarsandsense.org/archives/2004/1104spriggs.html.
} 
compares benefits and taxes of a reform proposal to "current law," with no adjustments made to reflect the looming insolvency of the system. ${ }^{77}$

Second, a large number of academic studies have shown the complexity of determining the amount of redistribution that occurs within the existing system. For example, studies of progressivity are extremely sensitive to issues such as whether the analysis is done on an individual or a household basis, on a year-by-year or a lifetime basis, and using actual or potential earnings. $^{78}$ Many of these studies conclude that there is actually very little progressive redistribution in the current system, which suggests that the appropriate baseline for comparing reform plans might be one in which the extent of income-based redistribution is already quite low.

Third, when evaluating the distributional effects of personal accounts, it is important to consider the disposition of the account assets when a worker dies. Many account proposals provide an inheritance benefit, such that the proceeds from the account of a deceased worker go to a surviving spouse, or, in the absence of a surviving spouse, to one's children or other named beneficiaries. Failing to properly account for these bequests, which can be quite beneficial to widows or widowers, can severely mislead any distributional analysis and lead to sweeping, yet incorrect, generalizations that "Social Security privatization hurts women."79 As another example, in the current system, a divorced woman whose marriage lasted less than 10 years has no right to any Social Security benefit from her ex-husband's earnings, whereas most personal account proposals contain provisions for some form of account sharing upon divorce. Academic

\footnotetext{
${ }^{77}$ An example of such an analysis is William E. Spriggs and David Ratner, "Social Security Price Indexing Proposal Means Benefit Cuts for Workers,” EPI Issue Brief \#209, 1 June 2005, http://www.epi.org/content.cfm/ib209.

${ }^{78}$ Alan L. Gustman and Thomas L. Steinmeier, "How Effective is Redistribution Under the Social Security Benefit Formula," Journal of Public Economics 82, no. 1 (2001): 1-28; Martin Feldstein and Jeffrey B. Liebman, eds., The Distributional Aspects of Social Security and Social Security Reform (Chicago: University of Chicago Press, 2002). ${ }^{79}$ The Democratic Party, "Social Security Privatization Hurts Women,” 31 March 2005, http://www.democrats.org/a/2005/03/social_security_3.php.
} 
work by Liebman and Feldstein analyzes a stylized personal account reform and concludes that "widows and widowers have not only greater proportional gains but also substantially more per capita benefits than married individuals. Divorced individuals also do well under the PRA plan relative to Social Security, especially if their former spouses are still alive or if their marriages lasted for fewer than ten years.” ${ }^{, 0}$

Fourth, when evaluating the distributional effects of a reform plan, it is necessary to consider the effects of all the policy changes in tandem, rather than on a piecemeal basis. For example, in Model 2 of the President's Commission to Strengthen Social Security, the personal accounts were designed to preserve the level of progressivity contained in the existing system, while certain changes to the defined benefit rules actually increased benefit payments for targeted low income individuals. Indeed, a June 2004 report by the non-partisan Government Accountability Office analyzed Commission Model 2 and found that such a plan "could result in lower earners receiving a greater relative share of all benefits than under the current system., ${ }^{.81}$ In other words, while Commission Model 2 reduced the overall size of the Social Security pie (in order to restore sustainable solvency to Social Security without payroll tax increases), low income workers would receive a larger share of the pie than under the current system.

The general point is that it is wrong to assume that the current Social Security system is progressive and that any reformed system would not be. The system can easily be changed to make the degree of redistribution greater than, less than, or equal to that of the current system. Broad and simplistic assertions that certain groups will necessarily win or lose by reform are unlikely to withstand careful scrutiny.

\footnotetext{
${ }^{80}$ Martin Feldstein and Jeffrey B. Liebman, "The Distributional Effects of an Investment-Based Social Security System,” in Feldstein and Liebman, eds., 281.

${ }^{81}$ Government Accountability Office, "Reform Proposals Could Have a Variety of Effects on Distribution of Benefits and Payroll Taxes,” GAO-04-872T, 15 June 2004, http://www.gao.gov/new.items/d04872t.pdf.
} 


\section{$\underline{\text { Conclusions }}$}

While the level of public discourse about Social Security has arguably never been higher than over the past year, not all of this discourse has been well-informed. The preceding analysis is intended to critically analyze ten of the leading myths that have been popularized by various sides in the Social Security reform debate.

The Social Security system is a very important part of the retirement security landscape in the United States. Due to changing demographics, however, the financial pressure being placed on its pay-as-you-go structure is not sustainable in the long run. As a result, it is a simple economic and mathematical necessity that the program be reformed in some way. While this article is not intended to prescribe solutions to Social Security's funding problem, a key message is that, regardless of whether or not personal accounts are created within the Social Security system, any reform effort will require changes to both the tax and the benefit side of the system's finances. A second message is that, given the importance of the Social Security system to the well-being of workers, retirees, the federal budget, and the U.S. economy, our nation needs a serious and thoughtful debate on how best to reform Social Security. While analysts may reasonably disagree over the most appropriate method of any reform, there should be little disagreement that the system is in need of reform and that acting soon to address the problem is preferable to doing nothing. 


\section{RECENT WORKING PAPERS FROM THE \\ CENTER FOR RETIREMENT RESEARCH AT BOSTON COLLEGE}

What Replacement Rates Do Households Actually Experience in Retirement?

Alicia H. Munnell and Mauricio Soto, August 2005

Bequests, Inheritances and Family Traditions

Donald Cox and Oded Stark, August 2005

Local Labor Market Conditions and Retirement Behavior

Dan A. Black and Xiaoli Liang, May 2005

Validation Study of Earnings Data in the SIPP_-Do Older Workers Have Larger Measurement Error?

Peter Gottschalk and Minh Huynh, May 2005

Investment Choice in the Swedish Premium Pension Plan

Mårten Palme, Annika Sundén, and Paul Söderlind, April 2005

Design and Implementation Issues in Swedish Individual Pension Accounts

R. Kent Weaver, March 2005

Lashed to the Mast?: The Politics of Notional Defined Contribution Pension

Reforms

Sarah M. Brooks and R. Kent Weaver, January 2005

Understanding Expenditure Patterns in Retirement

Barbara A. Butrica, Joshua H. Goldwyn, and Richard W. Johnson, January 2005

Changes in the Distribution of Long-Run Earnings and Retirement Incomes-Have Recent Cohorts Fallen Behind?

Peter Gottschalk and Minh Huynh, January 2005

The Age Profile of Income and the Burden of Unfunded Transfers in Four Countries: Evidence from the Luxembourg Income Study

Gary Burtless, December 2004

Projecting Immigration: A Survey of the Current State of Practice and Theory Neil Howe and Richard Jackson, December 2004

All working papers are available on the Center for Retirement Research website and can be requested by e-mail (crr@bc.edu) or phone (617-552-1762) 